The International Journal of Indian Psychology

ISSN 2348-5396 (e) | ISSN: 2349-3429 (p)

Volume 3, Issue 4, No. 59, DIP: 18.01.059/20160304

ISBN: 978-1-365-26307-1

http://www.ijip.in | July-September, 2016

\title{
Stress of Working Women
}

\author{
Dr. Latika Varma ${ }^{1 *}$
}

Keywords: Stress, Women, Modern Society

Stress is a major problem of today's modern society. It has been proved through recent studies that $75 \%$ of diseases occur due to mental stress, The deadly disease like heart disease and cancer too is related to stress. Now what is stress?

Psychologists have in many ways tried to define stress. The reason of mental stress has been made clear. Here, stress means the factor or event or cause through which there is mental disequilibrium, tension and maladaptive behaviour in the individual. Reber (1995) ahs rightly defined stress as 'Stress, generally is any force that when' applied to a system causes some significant connotation that the modification of its forms, usually with the connotation that the modification is a deformation or a distortion.

There is a stress provoking situation or event, which causes stress in an individual. It causes mental agony, worthlessness, frustration, depression and so on. This stress provoking situation can be physical, social or psychological, e.g. :- Physical disease, fatigue, pain etc. are the examples of Physical stress.

Similarly Social stress is related to that group of stimuli, which can cause mental agony and anxiety, e.g. :-Untouchability, unemployment, poverty, social status, etc. On the other hand psychological stress is caused by those incidence that initiates mental disequilibrium, e.g. :Death of someone near \& dear, marital maladjustment, loss of job, etc. are the major reasons for stress in any human being.

In other words we can say that Stress is highly related to psychological tension, Stress is just the outcome or effect of any incidents, not its cause. Reher has expressed this view in his words:"Stress is a state of psychological tension produced by physical, psychological and social forces and pressures."

Ruther's and Narid (1991) - "In psychology, Stress can be defined as demand on an organism to adjust, to cope or to adapt."

\footnotetext{
${ }^{1}$ Associate Professor, PG, Department Of Psychology, M.M.Mahila College, Ara, India *Responding Author

(C) 2016 I L Varma; licensee IJIP. This is an Open Access Research distributed under the terms of the Creative Commons Attribution License (http://creativecommons.org/licenses/by/2.0), which permits unrestricted use, distribution, and reproduction in any Medium, provided the original work is properly cited.
} 


\section{Stress of Working Women}

Darison Neale - (1996) _ " Stress is a state of organism subject to a stressor, it can the form of increased automatic activity and in the long ten, causes the breakdown of an organ or development of a mental disorder."

On the basis of above definitions, few points have been made clear:-

1. Stress is a mental and psychological condition of a individual.

2. This mental state is full of tension and anxiety.

3. This mental state develops due to many reasons.

4. The effect of outcome of such state of mind can be seen in, voluntary functions and may cause mental disorder.

\section{Signs and Symptoms of Stress:}

Physical:-

- $\quad$ Poor appetite or overeating.

- $\quad$ Feeling tired and fatigued.

- Various aches and pains - headache, body ache etc.

- $\quad$ Nausea and abdominal Pain.

- $\quad$ Sleep Problems.

- $\quad$ Falling sick very often - e.g.- Fever, cough \& cold, diarrhea (Because of lowering by immunity due to stress)

\section{Mental:-}

- $\quad$ Feeling Low

- $\quad$ Nervousness and Anxiety

- $\quad$ Excessive anger on Depression

- $\quad$ Being easily upset.

- $\quad$ Poor self confidence.

- Low self esteem

- Lack of concentration

- $\quad$ Poor work Performance

It may be also seen, that some amount of stress is essential for us to excel in life. This is GOOD STRESS or EUSTRESS.

But when stress is too much then it reduces performance. This is BAD STRESS on DISTRESS.

Dr. Hosamani Marilingappa (2016) finding her study Psychological distress was higher in those who knew their cancer diagnosis. It seems that the cultural issues and the way we provide information for cancer patients play important role in their improved or decreased psychological well-being. In her study 142 patients were selected for study. 


\section{Stress of Working Women}

According to Muddanagouda Patil (2016) Stress is a part of modern life, with increasing complexity of life, stress is likely to increase. Stress is built in the concept of role, which is conceived as the position a person occupies in a system. Women's in modern global world have to play a dual role as housewife and career builder. The present investigation was conducted to examine the stress among the working and non workingwomen's. It was hypothesized that the working women's has more stress than the non- working women's. In order to verify the above hypothesis a sample of 90 women's were taken. From which working women's $(\mathrm{N}=45)$ and non workingwomen's $(\mathrm{N}=45)$. To measure the stress, the stress scale developed by DR. M. Singh (2002) was administrated individually to the subjects. The data were subjected to 't' analysis and the major findings of the study reveals that the working women's has more stress than the non workingwomen's.

Rajeswari. H and Dr. B. Sreelekha (2016) concludes that majority of the nurses have stress. It is also found that stress due to work organization and inter personal relationship at work is harder which adds up to the stress. It is evident in the present study that younger age group and women were commonly affected with severe stress .Income earned and place where they live also influences the stress. It is recommended to implement strategies for reducing stress and to organize stress management programme.

In 2016, M Nikjeh done with the aim of examining efficacy of training stress-management by cognitive-behavioral method in decreasing stress symptoms of women suffering from breast cancer. The results of research showed that applied intervention led to reducing the stress of women who suffered from breast cancer and this efficacy was stable over time.

F Givi, F Kashani, S Vaziri, M Akbari (2016), observe in 23 women infected by breast cancer referring to Shohada Hospital of Shahid Beheshti University of Medical Sciences in Tehran by means of convenience and random sampling in two test (12 samples) and control (11 samples) groups. All examinees were evaluated firstly as respect to the distress rate by means of Kessler's distress assessment scale (K10), then de-stressing manner was trained to the test group during 8 sessions each one 90 minute. Control group has received any intermediation. The results of analysis of covariance of distress scores indicated that training stressful skills is effective on reducing the distress of women infected by breast cancer.

\section{Hypothesis}

To carry on any research, hypothesis has to be formed. Hypothesis is a tentative solution to a problem. This hypothesis can be confirmed or rejected on the basis of findings of research. Lundberg has rightly said that Hypothesis is a conjectural statement whose reliability is tested through research. 


\section{Stress of Working Women}

Hypothesis for the present research is "More stress is found among the lectures of affiliated colleges than in the lecturers of constituent colleges."

\section{Aims And Objectives}

The main objective of this research work is to find the stress level among the employees working in different professional organisations. The main aim is to know whether more stress is found among female lecturers working in constituent colleges or among the female lecturers working in an affiliated college.

Dr. A.K. Srivastava and Dr. A.P. Singh have constructed a scale for measuring the stress level. The "Occupational Stress Index" they have dealt with has 12 dimensions of stress in the index.

\section{They are:}

1. Role overloads 2. Role ambiguity 3. Role conflict 4. Powerlessness 5. Group and political pressure 6. Responsibility for persons 7. Under participation 8. Poor Peer relations 9. Intrinsic impoverishment 10. Low Status 11. Strenuous working conditions 12. Unprofitability.

All the twelve dimensions of stress are to be tested among the lectures of Constituent and Affiliated colleges.

\section{Research Procedures:}

The reliability and validity of any research work depends upon the research procedures. If the research procedures are not scientific, there is no meaning of research. A scientific research procedure is very essential to carryon any research work. In the present study following systematic Scientific research procedure and method has been adopted.

\section{Research Sample}

In this study two Constituent colleges H.D. Jain College, Ara \& Maharaja College, Ara and two Affiliated Colleges Veer Kunwar Singh College, Ara \& S.S.B. College, Simri all from Veer Kunwar Singh University, Ara taken.

Fifty lectures of both Constituent and Affiliated Colleges are selected through purposive sampling method.

\section{Research Instrument and Apparatus}

In this minor research project "Occupational Stress Index" has been used. Dr. A.K. Srivastava and Dr. A.K. Singh of B.H.U. Varanasi have developed this scale. Through this scale they have tried to measure the stress related to work conditions. There are altogether 46 questions with 5 probable answers:- Strongly Disagree, Disagree, Can’t Say, Agree and Strongly agree. It's a 5point scale. One answer has to be selected for each question by the sample. There are two types of Questions in it; one is False numbers of False Keyed Questions are 18, whereas the numbers of True Keyed Questions are 28. The Scoring of False Keyed Question is clone as 54321 . The 


\section{Stress of Working Women}

Scoring of True Keyed Question is done as 1234 5. The Score given for each question is added and Total Score is achieved. In this scale high Score denotes high Stress and Low Scored denotes Low Stress.

\section{Data Collection:}

Data collection is the key to any research work. In this research work, 50 lecturers of H.D. Jain College and Maharaja colleges are Constituent colleges under Veer Kunwar Singh University. Similarly 50 lecturers of S.S.B. College, simri \& Veer Kunwar Singh College, Ara were taken as sample. Both colleges are affiliated under Veer Kunwar Singh University.

\section{ANALYSIS}

Once the data was collected, its analysis was done on the basis of statistical method. Analysis of data was done by finding out mean, S.D. and T-ratio. After interpretation of data, it was found that stress like role overload, role ambiguity, role conflict, political pressure, under participation, powerlessness, poor peer relation, "intensive impoverishment, low status, strenuous working condition and Unprofitability, were more in the lectures of Affiliated Colleges compared to lecturers of constituent Colleges. Only the dimensions of Responsibility were more in the lectures of Constituent Colleges than in the lectures of Affiliated Colleges.

\section{CONCLUSION}

On the basis of the result obtained through mean, S.D. and t ratio it was concluded that the hypothesis that was formed is confirmed. We can say that more stress is seen in the female lecturers of Affiliated Colleges than the female lectures of Constituent Colleges.

\section{Acknowledgments}

The author appreciates all those who participated in the study and helped to facilitate the research process.

\section{Conflict of Interests}

The author declared no conflict of interests.

\section{REFERENCES}

Beehr, JA (1976)Perceived situational moderators of relationship between subjective role ambiguity and role strain. Journal of applied psychology.

Beehr, TA, Walsh , Relationship of stress to individual and organization

Brook, A,(1973)Mental stress at work.

Caplan, R D(1975) Effect of work load, role ambiguity and personality depression.

Cooper, C L7 Marshall, Jc Occupational source of stress.

Dr. Hosamani Marilingappa (2016) Anxiety and Depression in Patients with Gastrointestinal Cancer: Does Knowledge of Cancer Diagnosis Matter?, The International Journal of 


\section{Stress of Working Women}

Indian Psychology ISSN 2348-5396 (e), ISSN: 2349-3429 (p)Volume 3, Issue 3, No.1, DIP: 18.01.013/20160303, ISBN: 978-1-365-03416-9, http://www.ijip.in, April-June, 2016

F Givi, F Kashani, S Vaziri, M Akbari (2016), Effectiveness of De-Stressful Skills Training On Reducing the Distress of Women Infected by Breast Cancer, International Journal of Indian Psychology, Volume 3, Issue 4, No. 57, ISSN 2348-5396 (e), ISSN: 2349-3429 (p), DIP: 18.01.039/20160304, ISBN: 978-1-365-23993-9

M Nikjeh (2016), The Efficacy of Training Stress-Management by Cognitive-Behavioral Method in Decreasing Stress Symptoms of Women Suffering From Breast Cancer, International Journal of Indian Psychology, Volume 3, Issue 4, No. 58, ISSN 2348-5396 (e), ISSN: 2349-3429 (p), DIP: 18.01.040/20160304, ISBN: 978-1-365-24976-1

Muddanagouda Patil (2016) Stress Level of Working and Non Working Women, The International Journal of Indian Psychology , ISSN 2348-5396 (e), ISSN: 2349-3429 (p), Volume 3, Issue 2, No.4, DIP: 18.01.059/20160302, ISBN: 978-1-329-85570-0, http://www.ijip.in, January-March, 2016

Rajeswari. H, Dr. B. Sreelekha (2016) Stress among Nurses in a Tertiary Care Hospital, The International Journal of Indian Psychology ISSN 2348-5396 (e), ISSN: 2349-3429(p), Volume 3, Issue 2, No.2, DIP: 18.01.037/20160302 ISBN: 978-1-329-81573-5, http://www.ijip.in, January-March, 2016

How to cite this article: L Varma (2016), Stress of Working Women, International Journal of Indian Psychology, Volume 3, Issue 4, No. 59, ISSN 2348-5396 (e), ISSN: 2349-3429 (p), DIP: 18.01.059/20160304, ISBN: 978-1-365-26307-1 